\section{Planting Date and Rowcover Interactions in Broccoli Production in Cold Climates}

\author{
M.P. Westcott, N.W. Callan, and M.L. Knox \\ Western Agricultural Research Center, Montana Agricultural Experiment \\ Station, Montana State University, 580 Quast Lane, Corvallis, MT 59828
}

Additional index words. Brassica oleracea Italica Group, spunbonded polyester, netted polypropylene/polyamide, earliness, yield

Spring production of broccoli in western Montana is constrained by low early season temperatures. The crop is not normally transplanted to the field until early May, at which time soils average $16 \mathrm{C}$ at $0.1 \mathrm{~m}$. Methods that would enable earlier transplanting could extend the harvest season. Rowcover materials may provide this opportunity through temperature moderation, protection from light frosts, and reduced insect damage (Wells and Loy, 1985), although research on applications to cool-season vegetables has been limited to bunching onions (Mansour and Hemphill, 1987) and seed broccoli (MacFarlane Smith and Newbould, 1988). The objective of this study was to assess possible benefits of floating rowcovers to the production of broccoli cultivars differing in maturity date when planted at standard and early dates in the spring.

Split-plot factorial experiments in a randomized complete-block design with six replications were conducted in 1988 and 1989 on a Burntfork sandy loam soil. Main-plot rowcover treatments consisted of control (no cover), spunbonded polyester (SBP, 20 $\left.\mathrm{g} \cdot \mathrm{m}^{-2}\right)$, and netted polypropylene/polyamide (NPP, $17 \mathrm{~g} \cdot \mathrm{m}^{-2}$ ). Main plots were two rows $0.46 \mathrm{~m}$ apart, each row containing eight plants at a spacing of $0.30 \mathrm{~m}$. Single rows in each main plot were subplots of 'Packman' and 'Prominence'. This design was repeated each year in adjacent areas to attain early (13 Apr. 1988 and 18 Apr. 1989) and standard (9 May 1988 and 5 May 1989) transplanting dates.

The experimental plots were fertilized with $\mathrm{N}, \mathrm{P}$, and $\mathrm{K}$ at 112,50 , and $140 \mathrm{~kg} \cdot \mathrm{ha}^{-1}$, respectively. Rowcovers were loosely draped over 6-week-old transplants, anchored in the soil at the edges, and left in place until the first harvest date for each plot. The top 15 $\mathrm{cm}$ of the inflorescence and main stem of the middle six plants in each subplot was harvested and weighed at maturity.

With the early transplanting dates (Table $1)$, both rowcover materials consistently pro-

Received for publication 27 Aug. 1990. Montana Agricultural Experiment Station Journal no. J-2406. The cost of publishing this paper was defrayed in part by the payment of page charges. Under postal regulations, this paper therefore must be hereby marked advertisement solely to indicate this fact. moted earlier harvest and increased total yields in comparison to the control across cultivars and years. Significant rowcover $\times$ cultivar interactions with the first one or two harvest dates each year reflect the earlier maturity of 'Packman'. While yields tended to be higher with SBP than with NPP, these effects were not statistically significant.

Following standard transplanting dates (Table 2), both rowcovers promoted earliness of harvest compared to the control, as evidenced by significant rowcover effects at the first or second harvest dates. This occurred during both years of the experiment. transplanted 13 Apr. 1988 and 18 Apr. 1989. transplanted 9 May 1988 and 5 May 1989.
However, total cumulative yields were not affected by rowcovers or cultivar. Interactions between cultivar and rowcover treatments again reflect earlier harvests of 'Packman'.

The SBP and NPP rowcovers promoted earlier harvest and higher yields of broccoli planted 2 to 3 weeks before the standard early May transplanting dates. These effects were most consistent with SBP and likely reflect temperature modifications. At standard transplanting dates, the rowcovers promoted earliness but did not increase total yields over the uncovered treatment. Rowcovers, particularly SBP, are an effective tool for roadside growers wishing to reach market and attract customers earlier by planting broccoli earlier in the spring.

\section{Literature Cited}

MacFarlane Smith, W.H. and D.C. Newbould. 1988. The effect of covering material and nitrogen application on seed yield and quality of Brassica multiplications in seed production tunnels. Seed Sci. \& Technol. 16:445-455.

Mansour, N.S. and D.D. Hemphill, Jr. 1987. Bunching onion response to three floating row covers. HortScience 22:318-319.

Wells, O.S. and J.B. Loy. 1985. Intensive vegetable production with row covers. HortScience 20:822-826

Table 1. Rowcover effects on cumulative yields and mean head weights of two broccoli cultivars

\begin{tabular}{|c|c|c|c|c|c|c|c|c|}
\hline \multirow[b]{3}{*}{ Cultivar } & \multirow[b]{3}{*}{ Rowcover } & \multicolumn{7}{|c|}{ Cumulative yield $\left(\mathrm{g} \cdot \mathrm{m}^{-2}\right)$} \\
\hline & & \multicolumn{3}{|c|}{$\begin{array}{c}\text { Harvest date, } \\
\text { June } 1988\end{array}$} & \multicolumn{4}{|c|}{$\begin{array}{c}\text { Harvest date, } \\
\text { June } 1989\end{array}$} \\
\hline & & 7 & 10 & 15 & 7 & 20 & 13 & 23 \\
\hline \multirow[t]{3}{*}{ Packman } & Control & 52 & 281 & 281 & 0 & 64 & 371 & 371 \\
\hline & NPP & 358 & 427 & 427 & 42 & 265 & 553 & \\
\hline & SBP & 447 & 507 & 507 & 189 & 431 & 634 & \\
\hline \multirow[t]{3}{*}{ Prominence } & Control & 44 & 164 & 272 & 0 & 0 & 63 & \\
\hline & NPP & 0 & 314 & 386 & 0 & 0 & 310 & \\
\hline & SBP & 88 & 407 & 494 & 0 & 0 & 355 & 7 \\
\hline \multirow[t]{3}{*}{ Mean } & Control & 48 & 223 & 277 & 0 & 32 & 217 & 3 \\
\hline & NPP & 179 & 371 & 407 & 21 & 133 & 432 & 6 \\
\hline & SBP & 268 & 457 & 501 & 95 & 216 & 495 & 671 \\
\hline \multicolumn{2}{|c|}{$\mathrm{LSD}_{0.05}$ Cultivar (C) } & 72 & 66 & NS & 52 & 87 & 103 & NS \\
\hline \multicolumn{2}{|c|}{$\mathrm{LSD}_{0.05}$ Rowcover (RC) } & 105 & 107 & 119 & 57 & 126 & 127 & 147 \\
\hline \multicolumn{2}{|c|}{$\mathrm{LSD}_{0.05} \mathrm{C} \times \mathrm{RC}$} & 124 & NS & NS & 90 & 150 & NS & NS \\
\hline
\end{tabular}

Table 2. Rowcover effects on cumulative yields and mean head weights of two broccoli cultivars

\begin{tabular}{|c|c|c|c|c|c|c|c|c|}
\hline \multirow[b]{3}{*}{ Cultivar } & \multirow[b]{3}{*}{ Rowcover } & \multicolumn{7}{|c|}{ Cumulative yield $\left(\mathrm{g} \cdot \mathrm{m}^{-2}\right)$} \\
\hline & & \multicolumn{4}{|c|}{ Harvest date, 1988} & \multicolumn{3}{|c|}{ Harvest date, 1989} \\
\hline & & 29 June & 8 July & 14 July & 20 July & 26 June & 30 June & $5 \mathrm{July}$ \\
\hline \multirow[t]{3}{*}{ Packman } & Control & 0 & 212 & 605 & 668 & 215 & 686 & 686 \\
\hline & NPP & 225 & 625 & 649 & 698 & 416 & 604 & 604 \\
\hline & SBP & 187 & 543 & 649 & 681 & 647 & 647 & 647 \\
\hline \multirow{3}{*}{ Prominence } & Control & 0 & 80 & 506 & 883 & 0 & 259 & 556 \\
\hline & NPP & 0 & 280 & 569 & 1016 & 0 & 640 & 640 \\
\hline & SBP & 22 & 296 & 515 & 886 & 0 & 657 & 657 \\
\hline \multirow[t]{3}{*}{ Mean } & Control & 0 & 146 & 557 & 776 & 108 & 473 & 621 \\
\hline & NPP & 113 & 453 & 609 & 857 & 208 & 622 & 622 \\
\hline & SBP & 105 & 420 & 582 & 784 & 324 & 652 & 652 \\
\hline \multicolumn{2}{|c|}{$\mathrm{LSD}_{\mathrm{v} .0 \mathrm{~s}}$ Cultivar (C) } & 97 & 133 & NS & NS & 130 & 70 & NS \\
\hline \multicolumn{2}{|c|}{ LSD $_{0.05}$ Rowcover (RC) } & NS & 205 & NS & NS & 164 & 161 & NS \\
\hline \multicolumn{2}{|c|}{$\mathrm{LSD}_{0,05} \mathrm{C} \times \mathrm{RC}$} & NS & NS & NS & NS & 225 & 121 & 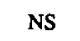 \\
\hline
\end{tabular}

